\title{
Post-harvest Loss Assessment of Banana (Musa spp.) at Jimma Town Market
}

\author{
Getachew Etana Gemechu ${ }^{1}$, Damtew Abewoy ${ }^{2} \&$ Kedir Jaleto ${ }^{3}$ \\ ${ }^{1}$ Jimma Agricultural Research Centers, EIAR, Ethiopia \\ ${ }^{2}$ Wondogenet Agricultural Research Center, EIAR, Ethiopia \\ ${ }^{3}$ Mehoni Agricultural Research Centes, EIAR, Ethiopia \\ Correspondence: Getachew Etana Gemechu, Jimma Agricultural Research Centers, EIAR, Ethiopia. E-mail: \\ getuetana2006@gmail.com
}

Received: January 12, 2021

Accepted: March 5, $2021 \quad$ Online Published: March 10, 2021

doi:10.5539/jps.v10n1p23

URL: https://doi.org/10.5539/jps.v10n1p23

\begin{abstract}
Post-harvest loss of banana in Jimma town market was accounted a total loss of $26.5 \%$ in the supply chain. Of these, more percent of the total losses were being observed at the retail market $(64.10 \%)$ and whole-salers level (35.90\%). Mechanical damage followed by improper transport and improper storage were identified as the main causes of banana loss at whole-salers level while fruit rotting followed by improper ripening and mechanical damage were identified as the main causes to the loss of banana fruit at retail level. Hence, the current post-harvest management system of banana at whole-salers and retail level is inadequate. There is no sufficient attention given for the post-harvest management of banana in the supply chain. It was also observed that, there is a knowledge gap between the respondents in their experience of proper fruit handling techniques. Therefore, to reduce the level of post-harvest losses of banana, more emphasis should be given to post-harvest handling practices. The loss can be minimized or prevented by awareness creation, education and training about the importance of post-harvest losses, adopting better management operations, careful handling and packaging to the supply chain actors.
\end{abstract}

Keywords: cause of post-harvest losses, post-harvest loss, post-harvest management

\section{Introduction}

Banana is one of the most commonly consumed fruits in the world and has great importance to small-scale farmers in the developing countries of the tropics and subtropics (Frison and Sharrock, 1999; Robinson and Sauco, 2010). About $87 \%$ bananas grown worldwide are produced by small-scale farmers for consumption or sale to local and regional markets (Frison et al., 2004). It has a multipurpose uses as food, feed, cash source and environmental conservation (Daniel, 1999). It is the most nourishing fruit and hence, a good source of potassium, magnesium, copper, manganese, vitamin C, B6 and others (Frison et al., 2004; Wall, 2006). Banana is also a good source of energy, low in protein and fat content and has several medicinal properties. Its attractive texture and flavor make banana popular by the consumers post-harvest

Dessert banana is also the major fruit crop that is most widely grown and consumed in Ethiopia (Bezuneh, 1975; Kahessay et al., 2010). In the south and southwestern parts of the country, it has a great socio-economic importance in rural communities including food security, income generation and job creation. In Ethiopia, banana covers about $57.95 \%$ (67,387.20 hectares) of the total fruit area; about $63.94 \%$ (5,394, 42.648 tones) of the total fruits produced and about $62.73 \%(5,462,709)$ of the total fruit producing farmers (CSA, 2020). An effort being made by the government of Ethiopia to promote and diversify its agricultural outputs as well as exports at large through research, extension services, investment endeavors and overall value-chain management. But its production has yet been limited to backyard and small-scale productions with the produce largely supplied to local markets. Large scale banana production in Ethiopia covers only $0.19 \%$ (1,910.97 hectares) of the total area covered by banana and $0.22 \%$ (17, 924.59 tones) of the total banana produced in Ethiopia (CSA, 2014).

The global share of Ethiopia in banana export was only $0.02 \%$ in 2011 (FAO, 2015) which could be described partly to problems associated with post-harvest handling to meet quality standards of the export market. A study 
conducted among producers, whole-salers and retailers of fruits in the fruit market chain revealed that, Losses of horticultural produce are a major problem in the post-harvest chain (Debela et al., 2011).

The study that was conducted in Ethiopia since 2015 revealed that, the average total farm level loss of banana was $15.6 \%$ of the total production due to improper transport and storage. The average total post-harvest losses at the whole-salers level were estimated to be $22.05 \%$ of the total produce handled/purchased for sale (Woldu et al., 2015).The causes of post-harvest losses accounted during banana transport from the farm gate to central markets, $20 \%$ percent of whole-salers purely reported impact and fruit breakage as cause of post-harvest loss while the rest $80 \%$ responded the cause to include physiological and other mechanical damages .The average total post-harvest loss at retailer level was estimated to be $8.05 \%$ which is low as compared with the other mainly due to the relatively rapid turnover of the produce. The main causes of post-harvest losses at the retail level include inappropriate display conditions and handling facilities (Woldu et al., 2015). Different studies had been done in different parts of Ethiopia regarding to post-harvest assessment of horticultural crops like banana. Therefore, this study was designed with the objectives of: to assess the extent of post-harvest loss of banana fruit at whole-salers and retail level at Jimma market; to assess the major causes of banana fruit loss at whole-salers and retailers' level and to assesses the different post-harvest handling practices of banana on the existing market level.

\section{Materials and Methods}

A survey was conducted to assess the extent of post-harvest losses of banana fruits and its causes along the whole-salers and retailers supply chain. The study was conducted at Jimma town, since February, 2017 which has been the major consuming town. Jimma is located at about $360 \mathrm{~km}$ southeast of Addis Ababa and is the dominant source of banana in the country. Mizan is one of the major sources of banana from where transported to jimma town market. Post-harvest losses at whole-salers and retailers were surveyed in Jimma town market by taking a total of 10 whole-salers and, 15 retailers who were randomly selected based on purposive sampling.

Primary data were collected with the aid of structured questionnaire. Based on the present context of banana marketing, two stages were identified to assess the post-harvest loss: whole-salers and retail levels. Two sets of questionnaires were scheduled and information on post-harvest handling and marketing practices were collected from participants at the two levels of the marketing chain. Data regarding losses at whole-salers and retail level were also collected separately. And finally, SPSS software was used to analyses the data obtained from the survey and then average means and percentages were used to compute post-harvest losses

\section{Results and Discussions}

\subsection{Extent of post-harvest Losses of Banana}

The total post-harvest loss of banana at whole-salers and retail level were found to be $29.25 \%$ (Table.1). The higher proportions of losses $(64.10 \%)$ were observed at retailer's level while the $35.90 \%$ losses were found at whole-salers level. The high percentage loss at the retailers could be accounted for the cumulative effect of improper handling from harvest to retailers' level. The perishable nature of ripe fruits also makes the problem worse at the retailers' level. The relatively lower magnitude of loss at whole salers' level could be explained by the fact that whole-salers are mostly dealing with green fruits. Though the damage is prevalent later at ripening, green fruits are more tolerant to handling problems. Similar to this, lower losses were reported by Wanjari and Ladaniya, (2004) for unripe bananas compared to the ripe ones.

Table 1. Post-harvest losses of Banana at whole-salers and Retail level

\begin{tabular}{lll}
\hline Supply chain & Loss $(\%)$ & Share in total (\%) \\
\hline Whole-sale level & 10.5 & 35.90 \\
Retail level & 18.75 & 64.10 \\
Total & 29.25 & 100 \\
\hline
\end{tabular}

\subsection{Causes of Post-harvest Losses of Banana at Whole-salers Level}

According to response of whole-salers $(28.15 \%)$, mechanical damage was the main cause for banana losses at whole-salers level, improper transport, improper storage, improper ripening and improper maturity which were noted by the remaining $22.71 \%, 19.46 \%, 17.26 \%$ and $12.42 \%$ of the respondents, respectively (Figure 1 ). The processes of fruit handling and packing from harvest through transport and marketing might contribute for mechanical damage to banana at whole sale market. Poor handling, unsuitable containers, improper packaging and transportation are indicated to easily cause bruising, cutting, breaking, impact wounding and other forms of injury leading to fruit deterioration (del Aguila et al., 2010). Similar results were reported by Ilayas et al. (2007) 
stating higher mechanical damage to bananas at whole sale and retail marketing than at harvesting level within the supply chain.

Whole-salers said that, long distance transport followed by poor packaging during transport and improper storage also had their own contribution for loss of banana fruit (Fgure 1). Transporting banana bunches without cushioning material may expose fruits to mechanical damage which resulting in losses (George and Mwangangi, 1994). This is particularly true when fruits are transported for long distance on rough roads, as it was the case in the present assessment. Improper maturity and ripening is one of the factors which perceived by whole-salers to have lower contribution to enhance banana loss. This might be because the whole-salers have limited awareness about the impact of their handling practice, which has their own contribution for banana loss.

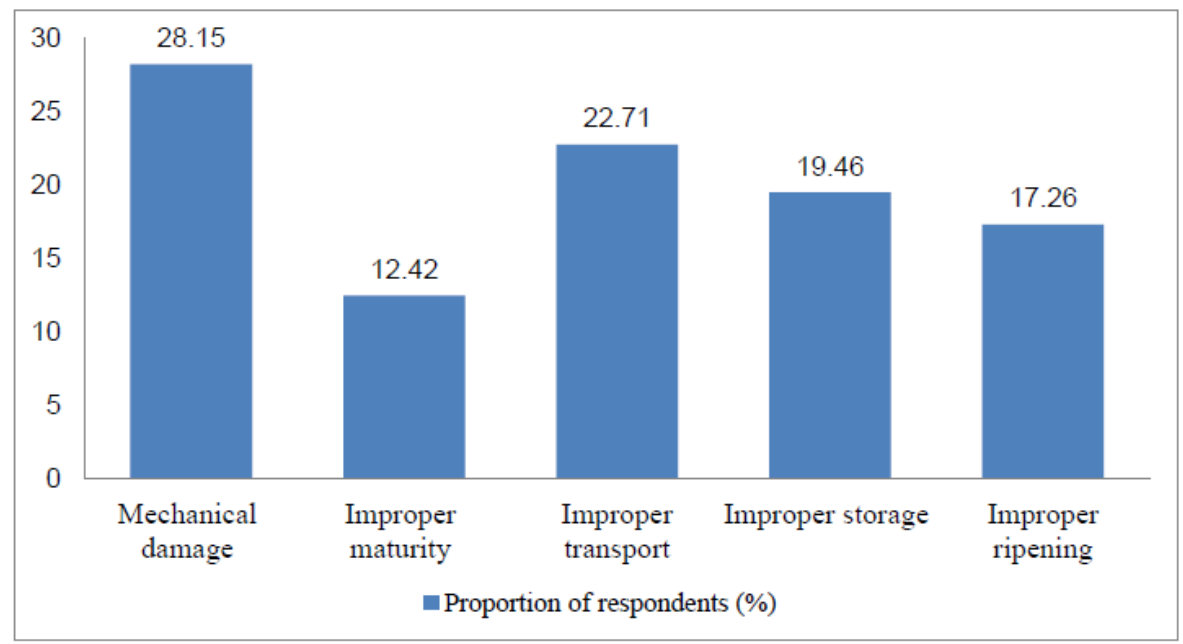

Figure 1. Causes of post-harvest loses of banana at whole-salers level

\subsection{Causes of Post-harvest Losses of Banana at Retail Level}

Fruit ripening was mentioned by majority of the retailers $(36.75 \%)$ as the main cause for banana fruit loss while improper ripening, mechanical damage, improper transport and improper maturity were noted by $28.26 \%$, $15.89 \%, 10.32 \%$ and $8.78 \%$ of the retailers, respectively (Figure 2). The possible reason to score high in rotting could be explained by the fact that during handling, fruits are infected with various pathogens which can be established at any time before or after harvest which resulted to cause decay in fruits. Banana pathogens gain entry through injuries happened during harvesting and injuries related to poor handling and transport. During storage, banana fruit deteriorates through the action of spoilage microorganisms, which become activated due to the changing physiological and biochemical state of the fruit (Turner, 2001). As evidenced from this assessment, unsatisfactory sanitation at the ripening and storage environments might also be the source of contamination and quality loss due to microbes; hence, all of which contribute to the spread of diseases to fruits. Moreover, the storage of fruits in boxes at retail market might result in more losses due to cross-contamination inside the crates. Similarly, poor hygienic conditions in the field and handling and mechanical injuries associated with poor transport and handling were reported to be the main causes for banana rot in Kenya (FAO, 2015). It is therefore, advised to reduce the incidence of physical injury and the risk of contamination of microbes and dust as a means of preventing fruits quality loss.

Improper ripening in banana fruit also leads to an increased susceptibility to physical damage and pathogen attack during storage which increases the risk of fruit spoilage at retail market. Microbial and mechanical damage also interact with the changing physiology of the fruit during ripening and storage will result in great fruit losses (Turner, 2001; Jun-Ping, 2006). The impact of mechanical damage might be increased at retail level because injuries from the previous handling chains will be more prevalent on the ripe banana fruit. The physiological state of the fruit (ripening) by itself also makes the fruit more sensitive to handling damages.

The retailers said that improper handling at whole-salers market and taking relatively longer days to sell fruits are the main causes favoring the loss of their fruit in the market (Table 3). It has been revealed that it took 4 to 5 days, which explained by most of the retailers $(53.45 \%)$ to finish selling their fruits. 


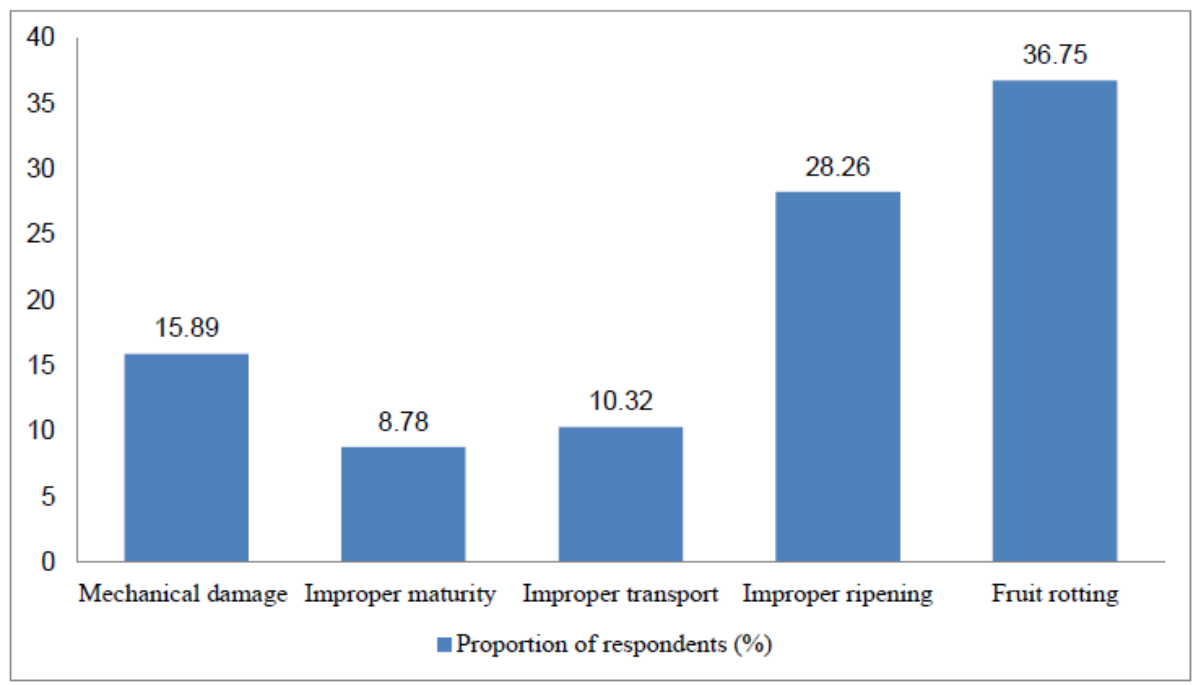

Figure 2. Causes of post-harvest loses of banana at retail level

\subsection{Banana Handling Practices at Whole-salers Level}

Fruits reaching the whole-salers market are off loaded and weighed before entering it to the ripening rooms. It was possible to observe during the assessment that labor handling during unloading was also very rough as they are in hurry just to finish their work. In the ripening room, majority of whole-salers $(42.85 \%)$ respond that, fruit bunches are stacked horizontally and receive airtight smoke treatment using kerosene burners to initiate the ripening process. There is no temperature and humidity control in the ripening rooms except that rooms are ventilated for some time. They said that, the smoke treatment days vary from 1 to 3 depending on the weather condition, relatively shorter time when temperature is high. Treated fruits are sold to retailers where further ripening is also expected at the retail market. Bananas which are not sold immediately after heat treatment will be de-handed and kept for sale heaped on floor, covered with newspaper $(40.5 \%)$, or kept on the shelf. Whole-salers (57.74\%) responded to finish selling their bananas within 3 to 4 days while it takes 5 to 7 days for the remaining $42.26 \%$. Wooden box was the major means of packaging material to transport banana fruit. For instance, $58.49 \%$ of whole-salers were responded as they used wooden box (Table 2).

Table 2. Banana fruit handling practices at whole-salers market

\begin{tabular}{lll}
\hline Handling practices & & Proportion of respondents (\%) \\
\hline \multirow{3}{*}{ Packing materials to transport } & Carton & 10.23 \\
& Wooden box & 58.49 \\
& Sacks & 18.12 \\
& Basket & 6.2 \\
& No packing & 6.96 \\
Ways of Ripening & Electric bulb +Kerosene & 22.41 \\
& Kerosene burners & 42.85 \\
Days to finish selling & Covering with leafy materials & 13.56 \\
& Cover with plastic woven sheet (Sacks) & 21.18 \\
Days to ripening & 3-4 days & 57.74 \\
& 5-7days & 42.26 \\
& 1-3 days & 48.7 \\
& 1 day & 21.36 \\
& 2 days & 29.94 \\
\hline
\end{tabular}

\subsection{Banana Handling Practices at Retail Level}

Retailers use different types of packaging materials to transport and store banana. Majority of retailers (57.65\%) use wooden boxes to transport their banana followed by baskets which accounts $25.4 \%$ of retailers are used this kind of materials and some retailers (2.58\%) use no packaging to transport banana fruits (Table 3). Most of the retailers $(51.88 \%)$ use plastic woven sheet (Sacks) and leafy materials $(20.96 \%)$ for ripening of their bananas. 
Most of the retailers (65.40\%), it takes 2 to 3 days for ripening of banana fruits while it takes 1 to 3 days for $34.60 \%$ retailers. It takes 4 to 5 days for most of the retailers $(53.45 \%)$ to finish banana selling followed by 7 days and 2 to 3 days with $28.12 \%$ and $18.43 \%$ of retailers respectively.

Table 3. Banana handling practices at retail market

\begin{tabular}{lll}
\hline Handling practices & & Proportion of respondents (\%) \\
\hline \multirow{3}{*}{ Packing materials to transport } & Carton & --- \\
& Wooden box & 57.65 \\
& Sacks & 14.23 \\
& Basket & 25.54 \\
& No packaging & 2.58 \\
\multirow{5}{*}{ Ways of Ripening } & Electric bulb + kerosene & 9.75 \\
& Traditional kerosene & 17.41 \\
& Covering with leafy materials & 20.96 \\
Days to finish fruit selling & Cover with plastic woven sheet (Sacks) & 51.88 \\
& 2-3 days & 18.43 \\
& 4-5 days & 53.45 \\
Days to ripening & 7 days & 28.12 \\
& 1-2 day & 34.60 \\
& 2-3 days & 65.40 \\
\hline
\end{tabular}

\subsection{Training Taken at Whole-salers and Retail Level}

According to the respondents, $30 \%$ of whole-salers are taken training before they engaged to this job by governmental organizations while only $6.67 \%$ of retailers are taken training before they engaged to be retailers for banana marketing (figure 3). Both whole-salers and retailers wanted any training and support regarding to post-harvest harvest handling of horticultural crops particularly for banana.

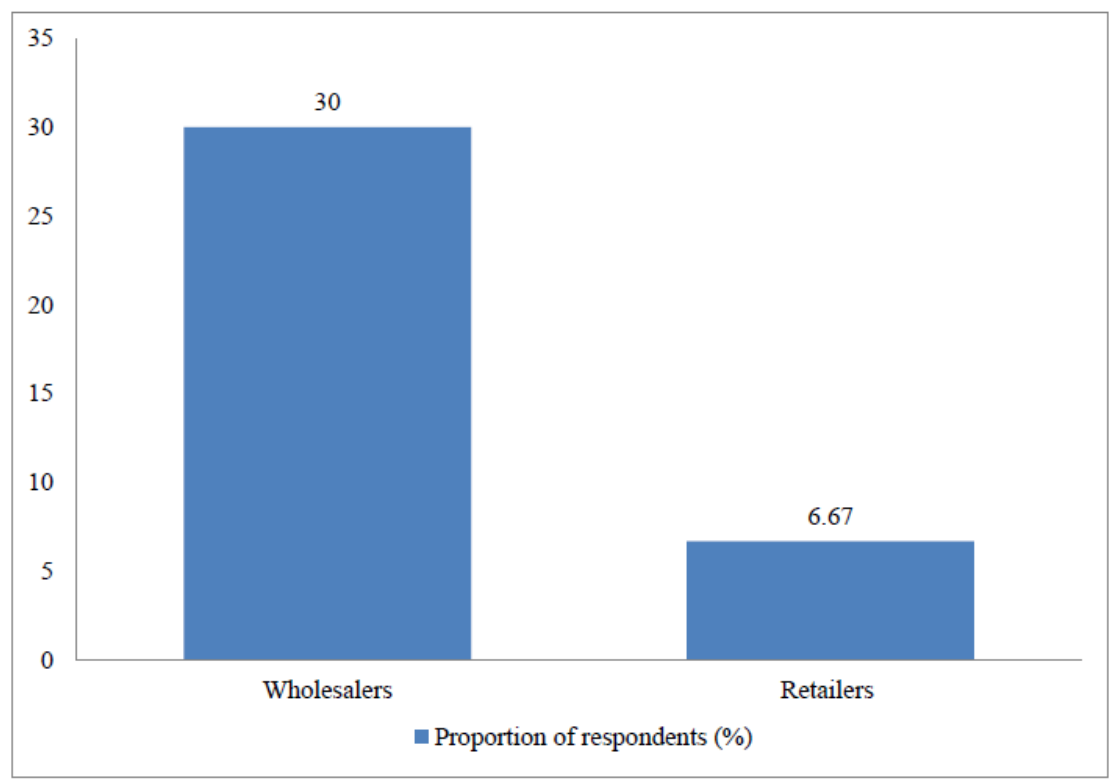

Figure 3. Whole-salerss and retailers who were taken training so far

\section{Summary and Conclusions}

Almost all types of bananas produced in Ethiopia are consumed fresh and play an important role in feeding the low income families as well as providing a source of income to them. The fact that it produces fruit throughout the year adds to its importance as a cash crop in the growing region. The post-harvest losses of banana in the supply chain with the total loss found to be $26.5 \%$ of which more percent of the total loss being at the retail market $(64.10 \%)$ and whole-salers level $(35.90 \%)$ in Jimma town market. Mechanical damage followed by 
improper transport and improper storage were identified as the main causes of banana loss at whole-salers level while fruit rotting followed by improper ripening and mechanical damage were identified as the main causes to the loss of banana fruit at retail level. Despite the fact that poor post-harvest handling during harvesting, transportation and marketing could have contributed more to the injuries noted, the respondent's perception for these factors to influence the loss was lower. It seems that the current post-harvest management system of banana both at whole-salers and retail levels is inadequate due to lack information about post-harvest handling practices. Therefore, in order to reduce the level of post-harvest losses of banana in Jimma market, focus should be given to post-harvest handling practices. The loss can be minimized by awareness creation, education and training about the importance of post-harvest losses, adopting better management operations, careful handling and packaging to the supply chain actors.

\section{References}

Adeoye, I. B., Odeleye, O. M. O., Babalola, S. O., \& Afolayan, S.O. (2009). Economic Analysis of Tomato Losses in Ibadan Metropolis, Oyo State, Nigeria. African Journal of Basic \& Applied Sciences, 1(5-6), 87-92.

Anthony, S., Abeywickrama, K., \& Wilson Wijerat-nam, S. (2003). The effect of spraying essential oils of Cymbopogonnardus, Cymbopogonflexuosusand Ocimumbasilicumon post-harvest diseases and storage life of Embul banana. Journal of Horticultural Science and Biotechnology, 78(6), 780-5. https://doi.org/10.1080/14620316.2003.11511699

Azene, M. (2015). Post-harvest loss assessment and management of banana (Musa spp.) fruit. PhD Dissertation.

Bathan, B. M., \& Lanican, F. A. (2010). Factors Affecting Performance of Banana Farms in Oriental Mindoro, Philippines. J.ISSAAS, 16(1), 110-120.

CFC (Common Fund for Commodities). (2004). Development of organic banana production and export in Sudan and Ethiopia to the Middle East and Europe. FC/CC/34/FISGB/10. Appraisal Report, Addis Ababa, Ethiopia.

CSA (Central Statistical Agency of Ethiopia). (2014). Agricultural Sample Survey. Report on Area and Production of Major Crops. Volume I, VII and VIII. Statistical Bulletin 578. Addis Ababa, Ethiopia.

CSA (Central Statistical Agency of Ethiopia). (2020). Agricultural Sample Survey. Report on Area and Production of Major Crops. Volume I, Statistical Bulletin 587. Addis Ababa, Ethiopia.

Daniel Shamebo, D. (1999). Banana in the southern region of Ethiopia (SRE). In C. Picq, E. Fouré, \& E. A. Frison (Eds.), Bananas and Food Security (pp. 119-128). INIBAP, Montpellier, France.

Debela, A., Daba, G., Bane, D., \& Tolessa, K. (2011). Identification of major cause of Post-harvest losses among selected fruits in Jimma zone for proffering veritable solutions. International Journal of Current Research, 3.

del Aguila, J. S., Heiffig-del Aguila, L. S., Sasaki, F. F., Tsumanuma, G. M., Ongarelli, M. G., Spoto, M. H. F., Kluge, R. A. (2010). Post-harvest modifications of mechanically injured bananas. Revista Iberoamericana de Tecnología Postcosecha, 10(2), 73-85.

Ethiopian Horticulture Development Agency. (2012). Annual Report. Addis Ababa, Ethiopia.

FAO (Food and Agriculture Organization of the United Nations). (2015). Production status.

Frison, E. A., Escalant, J. V., \& Sharrock, S. (2004). The global Musa genomic consortium: A boost for banana improvement. In S. M. Jain, \& R. Swennen (Eds.), Banana Improvement: Cellular, Molecular Biology, and Induced Mutations. Leuven, Belgium.

Frison, E. A., \& Sharrock, S. L. (1999). The economic, nutritional and social importance of bananas in the world. In C. Picq, E. Fouré, \& E. A. Frison (Eds.), Bananas and Food Security (pp. 21-35). J. INIBAP, Montpellier, France.

George, J. B., \& Mwangangi, B. M. (1993). Some factors affecting banana storage and ripening: a case study of banana handling and ripening in Kenya. International Symposium on Post-harvest Treatment of Horticultural Crops, 368, 628-633. https://doi.org/10.17660/ActaHortic.1994.368.73

Getachew, D. (2004). Prevention of post-harvest food losses fruits, vegetables and root crops a training manual. Agriculture and Consumer Protection.

Ilyas, M. B., Ghazanfar, M. U., Khan, M. A., Khan, C. A., \& Bhatti, M. A. R. (2007). Post-harvest losses in apple and banana during transport and storage. Pakistan Journal of Agricultural Sciences, 44(3), 534-539. 
Kahesaye, B., Puskur, R., Worku, T., Hoekstra, D., \& Azage, T. (2010). Innovation in banana value chain development in Metema district, northwestern Ethiopia: Improving productivity and market success (IPMS) project experiences. Acta Horticulture, 879: Produced by Economic and Social Development.

Robinson, J. C., \& Sauco, V. G. (2010). Bananas and Plantains (2nd ed.). CAB International, UK. https://doi.org/10.1079/9781845936587.0000

Salvador, A., Arnal, L., Manterde, A., \& Cuquerella, J. (2007). Reduction of chilling injury symptems in persimmon fruit cv. 'RojoBrillante by 1-MCP. Post-harvest Biology and Technology, 33(3), 285-281. https://doi.org/10.1016/j.postharvbio.2004.03.005

Tomek, W. G., \& Robinson, K. L. (1990). Agricultural Product Prices (3rd ed.). Cornell University Press, New York. pp. 107-108.

Turner, D. W. (2001). Bananas and plantains. In S. K. Mitra (Ed.), Post-harvest physiology and storage of tropical and subtropical fruits (pp. 45-77). CABI Publishing, UK.

Wanjari, V., \& Ladaniya, M. S. (2004). Marketing of banana in selected districts of India. Tropical Agricultural Research and Extension. pp. 126-133.

Woldu, Z., Mohammed, A., Belew, D., Shumeta, Z., \& Bekele, A. (2015). Assessment of Banana Production and Marketing in Ethiopia. International Journal of Sciences: Basic and Applied Research (IJSBAR), 24(3), 283-307.

Woldu, Z., Mohammed, A., Belew, D., Shumeta, Z., \& Bekele, A. (2015). Assessment of Banana Post-harvest Handling Practices and Losses in Ethiopia. Journal of Biology, Agriculture and Healthcare, 5(17).

Zhuang, J. P., Su, J., Li, X. P., \& Chen, W. X. (2006). Cloning and expression analysis of beta-galactosidase gene related to softening of banana (Musa sp.) fruit. Journal of plant physiology and molecular biology, 32(4), 411-419.

\section{Copyrights}

Copyright for this article is retained by the author(s), with first publication rights granted to the journal.

This is an open-access article distributed under the terms and conditions of the Creative Commons Attribution license (http://creativecommons.org/licenses/by/4.0/). 